\title{
(RE)CLAIMING ENGLISH LANGUAGE TODAY
}

\author{
Nadežda Stojković, University of Niš, Serbia, Nadezda.Stojkovic@elfak.ni.ac.rs \\ 10.31902/fll.26.2019.15 \\ UDK 811.111:005.44
}

\begin{abstract}
In the huge and most diverse discussion on the influence of the English language as a second, international, or bridge language, there are distinctive voices drawing attention to the fact that this language as nowadays so widely used in innumerable contexts, is no longer 'owned' by the community of speakers to whom it is mother language, those primarily of the countries from where English language originates. Moreover, the number of people speaking, or rather using English language today either as their second or foreign language, by far outnumbers people to whom it is native. Situation being such, it is further claimed the concept of 'standard English' reflects inherent inequality stance, for if it belongs to everyone speaking it, then insisting on the supremacy on only one of its variants means placing all those speakers of it in a subdued position, and this possibly being yet another facet of English an agent of neocolonialism and globalization (Pennycook 1998, Phillipson 1992). The spread of the English language has been much investigated as oppressive to the formation and expression of personal and collective identities, degrading national languages and through globalization diminishing the impact of local cultures (Bhaba 1990), that it challenges cultures and discourses, being the impetus for continuous re-codification and re-colonisation (Foucault 1980). However, equally significant in relevance and number, the opposing views claim English today offers an expanded community of users enabling new ways of expressing, changing, negotiating voices that offer chances for cultural renewal and exchange around the world, that the awareness of this brings "decolonizing of the colonizers mind" (Penycook 2013). Taking the flip side of the situation, English language natives are noted to be in a paradoxical situation of being expatriates from their own language, themselves "co-victims" (Bratlinger 1990). This insurgent knowledge of the status of English language today is certainly to instigate further investigation, 'writing back' of what ontology this language now embodies.
\end{abstract}

Key words: English language, globalization, neocolonialism, native speakers, ontology.

\section{Introduction}

English language is indisputably a lingua franca of the present, at once the initiator and agent of globalization. As such it is a socio-political fact, and so an ontology of globalization, of the social, political, ideological, economical processes that constitute it, and also a marker of identity and the language in which, with all these underlying layers of meaning constitution, history is writ- 
ten, read, interpreted. Because of these most complex forces, hereby briefly named, in much of contemporary debate, English is targeted as a major threat to local languages and identities, being accused of native languages endangerment, language death, linguicide (Phillipson and Skuttnab-Kangas 1995, 483).

Yet this process has a reverse perspective as well. Simultaneously, English language itself, its linguistic features and social perception, is affected by these intricate and far reaching changes, it is influenced upon as much as it influences. However, this viewpoint is not as much insisted upon in theory. The overarching argument stating this changing position of English language as acted upon reversely is the issue against of the 'ownership of English language' (Seidlhofer and Jenkins 2003; Widdowson 1994, 2003) and the 'single monochrome standard' (Quirk 1990) and for the pluri-centricity of English (so called World Englishes (Kachru 1992)). The paradox English language is experiencing is that whereas national languages worldwide are either being protected by national, institutionalized norms against the influx of English language (some national languages are undeniably being heavily influenced by English, some to the point of endangerment as is being argued), there are changes occurring in the English as well.

English language is claimed to belong to everyone speaking it worldwide over, and no longer belonging to countries and nations where it originates from, that this 'democratization' of English makes the dichotomy of native and nonnative users seems to have become obsolete, that it is a socio-linguistic fact that native speakers of English have lost the exclusive control of its standardization, and have in fact become a minority. There are even voices speaking of what (used) to be native speakers of English as expatriates from their own language. This tendency may be viewed as an attempt to resolve the power relations between native and nonnative users, making the language 'cross-culturally democratic', as certainly to some degree language is an index and an instrument of political power.

\section{Pluricentrism of English}

In 1985 Braj Kachru offered a three, concentric circle model, for current presence of English, those responding to the geographical and historical dimensions of English origin and spread. The inner circle thus marks the countries where English is a native language - UK, USA, the outer circle subsumes former colonies where English is a second language, and the third circle is the rest of the world where it is used as a foreign language (Kachru 1985). This model is important, among other reasons, for suggesting results of the use of institutionalized non-native English in multilingual and multicultural contexts and for raising important issues regarding (socio)linguistic theory, as well as ideological, 
broad social and psychological concerns. This particular use is claimed to influence the ontologies of the (new) varieties of English, the way English is learned in the pragmatic and interactional contexts, the forms of identities English now creates, possible ideological and social changes that result (Kachru 1990). The ensuing debate on the rationale of the existence of standard English or its negating certainly has an inherent ideology layer. It is a part of the contemporary social theory which is largely focused on unravelling and de-constructing covert or overt expressions of ideology embedded in social practices that stem from the dynamic opposition between a culturally dominant 'center' and a 'periphery' considered a margin ${ }^{1}$. Canagarajah (2002) warns that English carries within itself the possibility of linguistic imperialism (subsuming in itself other types of cultural neocolonialism) and therefore ideological domination.

In relation to the center/periphery dichotomy regarding Standard English, Alastair Pennycook states that English "is linked to inequality, injustice and the prevention of communication. Thus when we talk of language communities and the possible benefits of communication they may bring, we must also consider who is simultaneously left out of such cultural empires and what the consequences may be" $(2005,2)$.

Kachru's model implies recognition of multiple varieties of English, now called World Englishes, since at a global level a single norm of standard English is no longer used. "English belongs to everybody", the phrase by Robert Macneil (2003), illustrates in his opinion that in the present time of the unprecedented concern and "anxiety" about the spread of English language, an ever ongoing process of language change that is a sign of its "vitality and not decay", especially since English has a long history of language contact and language shift. This "evolutionary dynamics" (Kachru 1985) is accompanied by similar dynamism of the widespread emergence of hybrid mixes between English and local languages of Postcolonial Englishes as well as those in the Extending Circles, as English is being adopted by whatever means, in fragments and unconstrained of norm concerns, driven by strongly utilitarian considerations (Schneider 2014).

Furthermore, the long-standing dichotomy between native speakers (NS) and non-native speakers (NNS) of English has been profoundly challenged on linguistic, but also on ideological grounds. Linguists such as Pennycook, (1994, 2001), Widdowson, (1994), argue that the criteria used in labelling NSs/NNSs is

1 Kachru's model and theory built around it have instigated heated debate upon its validity. Reference to those is deliberately excluded here as being outside the topic. Yet, to give credit to it, an exemplary proponents of Standard English, Randolph Quirk, claims that without respecting the standard as established in UK (Received Pronunciation) or USA (General American) the varieties of this language would dissolve into being mutually incomprehensible, with English ultimately losing the function of being a bridge language. (Quirk 1990) 
a social construct rather that an index of linguistic competence. Combined with Kachru's model, this dichotomy favors Standard English as the only model to be emulated. Yet, there are many voices in linguistics but also related social theory, warning of the implications of treating Standard English as reserved for the "inner sanctum" (McGill 2000).

English language pedagogy worldwide gives supremacy to NSs in English speaking educational context without ever admitting that mere belonging to a nation whose mother tongue is English bears no connections to the proficiency in using that language - a fact obvious with any other mother tongue. To avoid and overcome this problematic dichotomy between NSs/NNSs, Widdowson (1994) presented the concept of 'ownership of English language' as a selfvalidated linguistic identity, and we argue identity as a whole. This owning of a language refers also to altering or not adhering to the norms of the center, the Standard English, where English varieties have different forms and functions. In the outer circle, primarily ex colonies, this language has had a long history of acculturation to local languages and cultures resulting in nativized discourse, style types, functionally determined registers (Kachru 1986). These new Englishes are still called nonnative varieties that follow nonnative norms (Kachru 1992, Strevens 1992). It is accepted that in these areas English has been changed by productive linguistic processes of lexical borrowings, morpho-syntactic transfer, semantic extension, pronunciation alterations, etc., all resulting in indigenization of English, which in short means that now these speakers follow the local languages norms and modify the English they speak accordingly. This is happening spontaneously, as multilayered linguistic transfer, without any conscious effort or institutionally pre-set requirement, showing how a language, especially a contact language modifies. Taking a critical stance towards this occurrence in an attempt to de-construct the 'center' supremacy paradigm of English usage on which the dichotomy between NSs and NNSs is based and sustained, which however is only social, not academic and which as such prevents insight into language change, by denigrating some varieties as peripheral or marginal (Mufwene 2001). Instead, what is suggested is adopting a pluri-centric view on this issue with non-native speakers in the outer circle seen as native speakers in their own right - acquiring and speaking the English language that evolved in their geographical, cultural and linguistic region.

\section{Ownership of English}

In 1994, Henry Widdowson affirmed the ownership of English by its speakers outside the historically conceived center. For him, indigenization of English is a new, alternative way of assessing mastery over that language, precisely using the term ownership to indicate ways of appropriating it. He further claims that 
endonormative standards cannot be used in exonormative settings, advocating that: "You are proficient in a language to the extent that you possess it, make it your own, bend it to your will, assert yourself through it..." (Widdowson 1994).

Much in the same vein, Kachru (1985) asserted that traditional norms of standardization as relating only to the Inner Circle are no longer sustainable, given the findings of contemporary socio-linguistics. He says that:

the global diffusion of English has taken an interesting turn: the native speakers of this language seem to have lost the exclusive prerogative to control its standardization; in fact, if current statistics are any indication, they have become a minority. This sociolinguistics fact must be accepted and its implication recognized. What we need now are new paradigms and perspectives for linguistics and pedagogical research and for understanding the linguistic creativity in multilingual situations across cultures. (30)

Widdowson, who supported this stance, made an even further assertion regarding the ownership over English today, namely that the countries where this language originates from, can no longer claim they are 'owners' of it. Once English has become international language, the claim over it shifted. "How English develops in the world is no business whatsoever of native speakers in England, the United States, or anywhere else. They have no say in the matter, no right to intervene or pass judgment. They are irrelevant. The very fact that English is an international language means that no nation can have custody over it. To grant such custody of the language is necessarily to arrest its development and so undermine its international status. It is a matter of considerable pride and satisfaction for native speakers of English that their language is an international means of communication. But the point is that it is only international to the extent that it is not their language. It is not a possession which they lease out to others, while retaining the freehold. Other people actually own it" (Widdowson 1994, 385). Seidlhofer and Jenkins (2003) confirm to Widdowson's claim that we are witnessing the ownership of English to have been passed from native to non-native speakers in the outer circle that suggest a form of global inclusiveness. Graddol $(1997,2006)$ also puts forward an argument that since English has definitely become a bridge language, its future in terms of how it changes is not upon its inner circle native speakers, but upon all users worldwide.

The arguments like these that question the present validity of standard English have an underlying perspective in common and that is to make this language more cross-culturally democratic. It is an acknowledgment that English is now not strictly confined to its primary lingua-cultural roots but has been disseminated to new communicative contexts of ever growing number of interactants with most diverse linguistic and cultural backgrounds. Insights into 
language change like this are based on the current fact that native-speaker norms are not conditional for an effective intercultural communication, but the negotiations of meaning between speakers. In that way the variants of English are neither correct or incorrect, they are proofs that cross cultural interaction is dependent on speakers effectively exploiting forms and functions of the given language for the purpose of communicating the desired meaning. The overall argument therefore is that Standard English is no longer to be considered the only reference, but that English, just like any other language is a flexible communicative means used by speakers of other languages who in their use of it in various ways mingle it with their/other languages and changing it in that way.

English language used this way is a lingua franca, its use in intercultural communication depends on its functionality rather than formal adherence to Standard English norms. In this situation, English demonstrated exolingual processes of appropriation for inter- and intra-national uses and is thus democratized and universalized.

\section{New Directions of Research to Follow}

The situation regarding the status and use of English today worldwide and its reference to Standard English hereby presented proves that this language is modified through appropriation for accomplishing the needed communicative acts regardless if that implies disregard for traditional norms. In other words, English as used today throughout the world is characterized by occasional application of unconventional features which in relation to the Standard are incorrect, but by functionality are wrong only by default. Widdowson $(2003,48)$ defines communication in this way saying that it means: "to exploit the resources of the language to produce a novel combination, not allowable by conventional code, but nevertheless a latent possibility which is virtual in the language not actually encoded."

The research that follows this phenomenon certainly does not aim to propose a new 'standard' of English language, but rather to promote awareness of linguistic accommodation and negotiation of meaning in intercultural communication that is based on the resources offered by English language, consequently advocating mutual understanding despite convergence from the original grammatical/pragmatic/pronunciation codes of that very same language. Instead of enforced adherence to language standard, this line of research emphasizes that language and thought are culture specific and culture bound which is the reason why English in the areas off the native countries and further on in its use as a lingua franca departs from its thereby standardized norms as influenced by the realities of other languages, cultures, practical demands of the given communicative situation, which in Pennycook's $(2010,685)$ words is "transcultural 
flows" of "translingual franca English." Language thus used for interactive situations throughout the world is continuously emergent and in that way "it sheds light on the most fundamental aspects of human communication" (Mauranen 2005, 270).

\section{Works Cited:}

Bhaba, H. Nation and Narration. Routledge. 1990.

Bratlinger, P. Rule of Darkness, British Literature and Imperialism 1830-1914. Cornell University Press. 1990.

Canagarajah, A. Critical academic writing and multilingual students. Ann Arbor, empires. Paper presented at the Institute of European Studies, February, 2005,

Foucault, M. Power/Knowledge: Selected Interviews and Other Writings, 1972 1977. Vintage. 1980

Graddol, D. The Future of English? London: The British Council. 1997.

Graddol, D. English Next: Why Global English May Mean the End of 'English as a Foreign Language'. London: British Council. 2006.

Kachru, B. "World Englishes and applied linguistics" in World Englishes, Vol. 9. No. 1. Pp. 3-20. 1990.

Kachru, B. B. (1992) “Models for non-native Englishes”. In B. B. Kachru (Ed.), The other tongue (2nd ed., pp. 48-74). Urbana: University of Illinois Press.

Kachru, B. The Alchemy of English. Urbana: University of Illinois Press. 1986.

Kachru, B.B. "Standard, Codification and Sociolinguistic Realism: The English Language in the Outer Circle," in R. Quirk and H. Widdowson (eds) English in the World: Teaching and Learning the Language and Literatures, Cambridge: Cambridge University Press, 1985.

Macneir, R. "English Belongs to Everybody" in The New Dimensions in Learning English, Eds. M. M. Flores et al. Rex Bookstore. 2003.

Mauranen, A. "English as lingua franca: An unknown language?". In Cortese, G., Duszak, A. (eds.). Identity, community, discourse. English in intercultural settings. Bern: Peter Lang, pp. 269-293. 2005.

McGill, S. Language Arts and Disciplines. Intellect Books. 2000.

Michigan: University of Michigan Press. 2002.

Mufwene, S. "New Englishes and norm setting: How critical is the nativespeaker in linguistics?" In E. Thumboo (Ed.), The three circles of English (pp. 133142). Singapore: UniPress. 2001.

Pennycook, A. "The Future of Englishes: One, Many, or None?," in A. Kirkpatrick (ed.) The Routledge Handbook of World Englishes, London: Routledge, pp. 673-688. 2010. 
Pennycook, A. Critical applied linguistics: A critical introduction. Mahwah, NJ: Erlbaum. 2001.

Pennycook, A. Global and worldly Englishes: Discommunities and subclutural. Berkeley, CA. 2005.

Pennycook, A. The cultural politics of English as an international language. New York: Longman. 1994.

Quirk, R. Language varieties and standard language. English Today, 21, 3-10. 1990.

Schneider, E. W. "New reflections on the evolutionary dynamics of world Englishes" in World Englishes, Vol. 33, No 1. Pp. 9-32. 2014.

Seidlhofer, B. \& Jenkins, J. English as a lingua franca and the politics of property. In Mair, C. (ed.) The Politics of English as a World Language: New Horizons in Postcolonial Cultural Studies. (ASNEL Papers 7) Amsterdam, New York: Rodopi. 2003.

Skutnabb-Kangas, Tove \& Phillipson, Robert. "Linguicide and Linguicism". In Phillipson, Robert \& Skutnabb-Kangas, Tove. Papers in European language Policy. ROLIG papir 53. Roskilde: Roskilde Universitetscenter, Lingvistgruppen, 1995.

Strevens, P. English as an international language: Directions in the 1990s. In B. B. Kachru (Ed.), The other tongue (2nd ed., pp. 27-47). Urbana: University of Illinois Press. 1992.

Widdowson, H. G. "The ownership of English". TESOL Quarterly, 31, 377-389. 1994.

Widdowson, H. G. Defining issues in English language teaching. Oxford: Oxford University Press. 2003.

\section{PRISVAJANJE ENGLESKOG JEZIKA}

$U$ društvenoj teoriji danas postoje najraznovrsnije rasprave of uticaju engleskog jezika kao drugog jezika, kao i jezika međunarodne komunikacije, u kojima se izlaže teza da engleski jezik više ne 'poseduju' narodi koji su ga stvarali, da ne pripada više samo zemljama u kojima je maternji. Centralni argument za ovu tvrdnju jeste da je broj ljudi koji koriste engleski jezik kao svoj drugi ili strani, danas daleko veći od broja ljudi kojima je on prvi jezik. Posledično, tvrdi se da koncept 'standardnog engleskog' implicira nejednakost, jer kako ovaj jezik danas koriste ljudi raznih nacija, njihova varijanta nije ništa manje 'pravilna' od dosadašnjeg standarda Velike Britanije ili SAD. Insistiranje na 'standardu jezika' ovih zemalja pokazuje još jedan kritikovani aspect upotrebe engleskog kao agenta neokolonijalizma i globalizacije (Pennycook, 1998; Phillipson, 1992). Širenje upotrebe engleskog jezika razmatra se i kao opresivni uticaj na formiranje i izražavanje ličnih i kolektivnih identiteta, na nacionalne jezike i kulture (Bhaba, 1990), te da predstavlja impetus za ponovnu kolonizaciju (Foucault, 1980). 
Ipak, danas su jednako važni i glasovi koji ukazuju da ovakva rasprostranjena upotreba engleskog jezika omogućava i nove načine izražavanja koji doprinose kulturnoj razmeni širom sveta, tako da svest o ovome znači „dekolonizovanje kolonizovanog uma" (Penycook, 2013).

Kada se u ovom kontekstu sagleda pozicija ljudi kojima je engleski maternji jezik, uočava se paradoks da su oni u egzilu u sopstvenom jeziku (Bratlinger, 1990). Upotreba engleskog jezika zahteva dalju, opsežnu, interdisciplinarnu analizu ontologije koju ovaj jezik predstavlja.

Ključne reči: engleski jezik, globalizacija, neokolonijalizam, maternji jezik, ontologija. 